\title{
A KÖRNYEZETTUDATOS CSELEKVÉSEK ELEMZÉSE
}

Egyre több jel utal arra, hogy manapság a globális környezeti problémák korszakában él az ember. Cselekvéseivel hozzájárul a környezet állapotának romlásához vagy javulásához. Emiatt kiemelt jelentőségű az egyének környezettudatos magatartásának elemzése, a környezettudatosság szintjének számszerűsítése és a kapott eredmények összehasonlítása az egyének önértékelésével, azzal, hogy mennyire tartják önmagukat környezettudatosan viselkedő személynek. Ennek érdekében 2017 tavaszán egy 442 fős online kérdőíves felmérést végezett a szerző. A kutatás során a módosított általános környezettudatos cselekvések skáláját (PEB) alkalmazta, amely segítségével egy cselekvési nehézségekkel súlyozott skálán meghatározta az egyéni környezettudatosság szintjét. Kutatási eredményei alapján megállapítható, hogy hazánkban a környezettudatos magatartás általános szintje alacsony, és az is, hogy a nem környezettudatos módon élők sokkal környezettudatosabbnak gondolják magukat a valóságnál, azaz szignifikánsan kedvezőbb az önértékelésük a ténylegesnél. A tanulmány mindezeken kívül különféle statisztikai módszerek segítségével részletesen elemzi a különféle környezettudatos cselekvési típusokat, bemutatja a leggyakoribb és legritkább környezettudatos cselekvéseket, a cselekvésekhez kapcsolódó nehézségeket, valamint megvizsgálja a láthatóság, az egyéni haszon és a környezettudatos magatartás közötti kapcsolatokat.

Kulcsszavak: környezettudatos magatartás, környezettudatos cselekvések, láthatóság, egyéni haszon, cselekvési nehézség, önértékelés

A klímaváltozás gyorsulása, a Földünk által küldött vészjelek egyértelművé teszik, hogy a környezeti problémák korában élünk és ez paradigmaváltást igényel a marketingben is a társadalmilag felelős fogyasztás előmozdítása érdekében (Rekettye - Rekettye, 2009). A fenntarthatósággal foglalkozó szakirodalom szinte teljesen egyetért abban, hogy a legtöbb környezeti probléma oka az egyének magatartásában, mindennapi cselekedeteikben keresendö, beleértve a fogyasztást, a hulladékok kezelését, az utazást és az energiahasználatot (Boldero, 1995; Oskamp, 2000; Nordlung - Garvil, 2002; Ojala, 2008; Swami - Chamorro-Premuzic - Snelgar - Furnham, 2011; Guerrero - Maas - Hogland, 2013; Marshall - Farahbakhsh, 2013). Ebből az következik, hogy az egyének környezettudatos cselekvéseinek az összessége határozza meg egy társadalomban a környezettudatos magatartás tényleges szintjét. Hofmeister-Tóth Ágnes (2016) szintén rámutat az egyének felelősségére. Álláspontja szerint, a fenntarthatóság kialakításában a fogyasztóknak is kiemelt szerepük van a vállalatok és az állam szerepvállalása mellett. Ezt a felelősséget viszont csak kevés fogyasztói, befektetői, választópolgári vagy alkalmazotti szerepet betöltö állampolgár ismerte fel eddig.

A környezettudatos magatartás a legszélesebb definíciója szerint magába foglal minden olyan tevékenységet és magatartást, amely a lehető legkisebb mértékben ártalmas a környezetre, vagy még esetleg hasznos is számára (Steg Vlek, 2009). A környezettudatos cselekvések elemzése azonban annak ellenére egy viszonylag kevésbé kutatott terület hazánkban, hogy néhány tanulmány már részben érintette a környezettudatos magatartás elemzése során (Nagy, 2005; Nagy - Piskóti - Molnár - Marien, 2012; Hofmeister-Tóth Kasza-Kelemen - Piskóti, 2013; Piskóti, 2015).
A tanulmányom alapvető célja a környezettudatos cselekvések feltérképezése, melynek elérése érdekében az alábbi részcélokat határoztam meg:

- a környezettudatos cselekvési típusok és a tényleges környezettudatos cselekvések elemzése,

- a környezettudatos cselekvésekhez kapcsolódó cselekvési nehézségek számszerüsítése,

- a környezettudatos cselekvések alapján a környezettudatos magatartás tényleges szintjének a meghatározása,

- a láthatóság környezettudatos magatartásra gyakorolt hatásának a vizsgálata,

- a környezettudatos magatartás önértékelésének és tényleges szintjének összehasonlítása.

\section{A KÖRNYEZETTUDATOS CSELEKVÉSEK}

Egy egyén környezettudatos magatartása az általa véghez vitt környezettudatos cselekvések számától és azok nehézségétől függ. Kaiser (1999) azt javasolja, hogy az egyéni kontrollon kívül eső hatásokat (szituációs hatások) két különböző módon vegyük számításba:

- a környezettudatos magatartás valószínüségének becslésével (általában véve mennyire környezettudatos az egyén), illetve

- annak a valószínüségnek a kifejezésével, hogy valaki egy bizonyos környezettudatos cselekvést megvalósít (tényleges cselekvési nehézség).

Meffert és Kirchgeorg (1994) szerint a környezettudatos cselekvési típusok öt csoportba sorolhatók melyek az alábbiak: 
1. a hagyományos termékek fogyasztásának csökkentése, illetve róluk való lemondás,

2. keresletmódosítás: környezetbarát termékek vásárlása a hagyományos helyett,

3. környezethatékony termékek fogyasztása,

4. részvétel az újrahasznosításban, a szelektív hulladékgyüjtésben,

5. környezettudatos panasz, tiltakozás.

A cselekvési típusok a vásárlási döntési folyamat egészét átfogják, sőt a vásárlás előtti és az azt követő szakaszra is kiterjedhetnek. Az első, a második és a negyedik típusú viselkedést szokásokon alapulónak (habituális) tekinthetjük. Ezek megváltoztatása nagyon nehéz, hiszen évek, akár évtizedek alatt kialakult szokásokról van szó, melyek nagy részét a gyermekkorban vesszük fel. Ezek a szokások mélyen beleivódnak az egyénbe, megváltoztatásuk rengeteg időt és energiát igényel (Hofmeister, 2003). A változási folyamat meggyorsítható a referenciacsoportok segítségével olyan pozitív fogyasztási minták bemutatásával, amelyeket a megváltoztatni kívánt személy nagyra értékel, vagy ha kognitív disszonanciát ébresztünk a fogyasztóban, mégpedig úgy, ahogy azt a dohánytermékeken a jogi kényszer miatt feltüntetett feliratok teszik.

A hagyományos termékek fogyasztásának csökkentése az első lépésnek tekinthető a környezettudatosabb vásárlóvá válás útján. Sokkal nagyobb fokú tudatosságot kíván meg a hagyományos termékekröl való részleges lemondás. Ennek egyik oka a helyettesítő környezetbarát termékek hiányában keresendő, a másik oka pedig lehet a fogyasztói megszokás, illetve a kényelmi tényező. A teljes lemondásról csak bizonyos termékek esetében és csak egészen ritkán beszélhetünk. Ezt a fajta fogyasztást testesíti meg a hedonizmus ellentrendjeként megjelent az új aszkétizmus, amely az önmegtartóztatást és megfelelő anyagi háttér melletti lemondásokat foglalja magában (Törőcsik, 2011).

Az átlagosnál erősebb fogyasztói környezettudatra utal a környezetbarát termékek vásárlása. A hagyományos termékek fogyasztásának csökkentése és környezetbarát termékek vásárlása egyaránt a fogyasztók költség-haszon elemzésén alapulnak. Meffert és Kirchgeorg (1994) szerint a termékhasználatból az alábbi költségek vagy hasznok származhatnak:

- egyéni költségek (árak, fáradozás stb.),

- egyéni haszon (teljesítmény, időmegtakarítás stb.),

- extern (társadalmi) költségek (lég-, vízszennyezés stb.),

- extern (társadalmi) haszon (nyersanyagkímélés, jobb levegő stb.).

Ezek közül az extern költségek és hasznok csak hosszú távon lépnek fel, míg az egyéniek általában rövid távon. Az externáliák jellemzői közé tartoznak, hogy harmadik személy (vagy személyek) jóléti függvényét módosítja, nincs ellentételezés és az előidézett hatás nem szándékolt.

A szelektív hulladékhasznositási készség előfeltétele az, hogy az egyéni haszon és a társadalmi költségek közötti összefüggéseket felismerje a fogyasztó. Ez a fajta viselkedés alacsony egyéni haszonnal jár és magas egyéni költségeket feltételez. Ilyen cselekvést a közgazdasági értelemben racionálisan viselkedő egyén nem fog önmagától kezdeményezni, hacsak nem részesül valamilyen kompenzációban, illetve nem kényszerítik erre valamilyen jogi vagy gazdasági eszközzel. Az egyéni haszonnak kompenzálnia kell az egyéni költségeket ahhoz, hogy a felhasználó a keletkező hulladékát környezettudatosan, azaz szelektív módon gyüjtse (Meffert - Kirchgeorg, 1994). Fontos az is, hogy a szelektív gyüjtésben részt vevő teljes körü tájékozottsággal rendelkezzen a gyűjtési rendszer müködéséröl, beleértve a szelektív módon gyüjtött hulladék további útját is (Nagy, 2004).

A panasz-tiltakozás formájú viselkedés megértéséhez Hirschman (1970) Exit-Voice elmélete szolgál alapul, mely kimondja, hogy a fogyasztó az áruval kapcsolatos elégedetlenségét kétféle úton fejezheti ki. Egyrészt valamilyen szempontból jobb áru vásárlásával (exit) vagy véleményének panasz, vagy tiltakozás formájában történő kinyilvánításával (voice). A hagyományos termékváltozatokkal szembeni kinyilvánított fogyasztói elégedetlenség utat törhet a környezetbarát termékek iránti kereslet számára. A hagyományos termékkel elégedetlen fogyasztó egyrészt vásárolhat környezetbarát termékeket (exit), másrészt különböző fórumokon hangot adhat elégedetlenségének (voice). Emellett tapasztalati megfigyelések mutatják, hogy a fogyasztók képesek jelentős negatív szájreklámot csapni egy-egy olyan terméknek vagy szolgáltatásnak, amellyel nincsenek megelégedve. Ez teljes mértékben imázsromboló hatású, főleg akkor, ha a média támogatását is elnyeri.

A környezettudatos cselekvések esetében fontos kérdés azok láthatósága. Ez alatt azt értem, hogy a cselekvés látható-e mások számára, észreveszik-e, észlelik-e mások, ha környezettudatosan, vagy éppenséggel nem környezettudatosan viselkedek. A társadalmi identitás ,az egyik legfontosabb pszichikus közvetítő konstrukció az egyén és a társadalom között" (Pataki, 1982, p. 248.). A társadalmi identitásból következtetni lehet a környezettudatos magatartás bekövetkezési valószínűségére, azonban ennek mértéke attól is függ, hogy a környezettudatos cselekvés látható-e mások számára. A láthatóság általában pozitív hatást gyakorol a környezettudatos magatartásra, mert ennek hatására sokan választanak környezetbarát termékeket a hagyományosok helyett (Griskevicius - Tybur - Van den Bergh, 2010), vagy kevesebbet szemetelnek (Bateson - Callow - Holmes - Redmond Roche - Nettle, 2013).

Amikor egy általában környezettudatosan viselkedő személy úgy gondolja, hogy a környezettudatos magatartása mások számára is látható (pl. újrahasznosított bevásárlótáska használata a vásárlás során), akkor a referenciacsoport hatása miatt nagyobb lesz a valószínűsége annak, hogy az adott cselekvés vonatkozásában (bevásárló táska használat) valóban környezettudatosan fog viselkedni. Ezzel szemben az is megfigyelhetö, hogy az egyáltalán nem környezettudatos emberek viselkedése még kevésbé lesz környezettudatos, ha úgy hiszik, hogy mások is figyelik őket (Brick - Sherman - Kim, 2017). 
Piskóti (2015) mindezeket azzal egészíti ki, hogy a környezeti identitásnak közepesen erős pozitív hatása van a környezetbarát tevékenységre és az általa vizsgált pszichográfiai tényezők közül az identitás rendelkezett a legjelentősebb hatással a viselkedés kialakulására.

Mindezek alapján fogalmaztam meg az alábbi hipotéziseimet:

- a környezettudatos cselekvések láthatósága pozitív hatást gyakorol a tényleges környezettudatos magatartásra (H1),

- az átlagosnál jóval környezettudatosabb egyének esetében a cselekvés láthatósága növeli annak bekövetkezési esélyeit, míg a nem, vagy egyáltalán nem környezettudatos egyének esetében csökkenti azt (H2).

A hazai kutatási eredmények közül kiemelendő, hogy Hofmeister-Tóth, Kasza-Kelemen és Piskóti (2013) az Általános Környezettudatos Magatartás (General Ecological Behavior) skála (Kaiser - Wilson, 2004) alkalmazásával feltárták, hogy a magyar lakosság leggyakrabban az energia- és vízmegtakarításhoz kapcsolódó környezettudatos cselekvéseket végzi. Véleményük szerint azért, mert az embereknek anyagi előnyük származik belölük, ezáltal nemcsak a környezetet, de a pénztárcájukat is védik a fogyasztók. Felmérésükben ezt követték a közlekedéshez kapcsolható cselekvések, illetve a szelektív hulladékgyüjtéshez és a hulladékcsökkentéshez kapcsolódó magatartásformák. Kutatási eredményeik szerint a legkevésbé fordulnak elő a társadalom számára hasznos környezetbarát cselekvések, beleértve a környezetvédő szervezetek anyagi támogatását, illetve a vállalatok bojkottálását.

\section{MÓDSZERTAN}

A környezettudatos cselekvések feltérképezése és a környezettudatos magatartás mértékének számszerüsítése érdekében a Kaiser, Wölfing és Fuhrer (1999) által megalkotott Általános Környezettudatos Magatartás skála (angolul: General Environmental Behaviour Scale, rövidítve GEB) módosított verzióját alkalmaztam. Ez egy olyan skála, ahol minden egyes cselekvéshez rendelhető egy, a cselekvés végrehajtására vonatkozó nehézségi fok, amely a nem kontrollálható kényszer nagyságát fejezi ki. Minél nehezebb egy környezetbarát cselekvést megvalósítani, annál nagyobb egyéni kontrollon kívül eső kényszer feltételezhető az adott cselekvés esetén. A cselekvési nehézséget úgy lehet kiszámolni, hogy minden egyes cselekvés esetén figyelembe vesszük, hogy mennyien viselkednek környezettudatos módon az adott cselekvés vonatkozásában. Azt, hogy valaki általában véve mennyire hajlamos a környezettudatos viselkedésre, úgy számolhatjuk ki, hogy számításba vesszük azon cselekvések számát, ahol az illető környezettudatos módon viselkedett. Mivel ez a módszer egy adott személy környezettudatos magatartásának mérése során számításba veszi az általában vett környezettudatos viselkedés iránti hajlamot, valamint a cselekvési nehézségeket is, ezért lehetséges az is, hogy az emberek bizonyos mértékben inkonzisztens módon is viselkedjenek. Így for- dulhat elő az, hogy valaki általában véve sok tekintetben környezettudatosan viselkedik, de például zuhanyozás helyett inkább fürdőzni szeret, azaz nem lesz környezettudatos egy olyan cselekvés során, amely esetében az emberek többsége inkább környezettudatosan viselkedik. De az is előfordulhat, hogy valaki, aki alapjában véve egyáltalán nem környezettudatos, környezettudatosan fog viselkedni egy olyan cselekvés esetében, ahol nagyon magas a cselekvési nehézség szintje (pl. soha nem használ autót, mert nem engedheti meg magának anyagilag).

A környezettudatos magatartás modelljének tesztelése során az eredeti, Kaiser, Wölfing és Fuhrer (1999) nevéhez füződő 38 állítást tartalmazó GEB-skálától részben eltérő, aktualizált, módosított skálát alkalmaztam, amelyet PEB-skálának neveztem el a környezettudatos magatartás angol elnevezésének (Pro-Environmental Behaviour) rövidített formája (PEB) után. A PEB-skálába a társadalmi felelősséget (Social Desirability) vizsgáló kérdéscsoportot már nem vontam be, mivel a Kaiser (1999) feltárta, hogy a társadalmi felelősség a környezettudatos viselkedésre alig érzékelhető hatást gyakorol. További négy, környezettudatos viselkedésre vonatkozó állítást az értelmezési nehézségek vagy a relevancia hiánya miatt hagytam ki a PEB-skálából. Az alábbi cselekvések már nem szerepeltek a módosított mérési konstrukcióban:

- a szupermarketekben általában a gyümölcsös ládából vásárolok gyümölcsöket,

- fogalmam sincs arról, hogy tankolhatok-e ólmozott benzint az autómba,

- a fürdőszoba takarításakor speciális tisztítószereket használok az általános célúak helyett,

- foszfátmentes mosószereket használok.

Helyettük az alábbi tizenegy darab, újonnan hozzáadott cselekvéssel kívántam pontosabban felmérni a tényleges környezettudatos magatartás szintjét hazánkban:

- amennyiben lecserélek egy háztartási gépet, mindig energiatakarékosabbat vásárolok,

- nem cserélek le semmit csak azért, mert kiment a divatból,

- legszívesebben a húst is hússal enném,

- évente legalább egyszer-kétszer utazom repülőgéppel nyaralni, vagy üzleti ügyben,

- sok újrafelhasznált anyagokból készült terméket (pl. WC-papír) vásárolok,

- általában olyan helyi termékeket, élelmiszert vásárolok, amelyeket nem messziröl szállítanak ide,

- nem vásárolok olyan termékeket, melyekről tudomásom van, hogy kifejlesztése során állatkísérleteket végeztek,

- jóval kevesebb hulladék keletkezik a háztartásunkban, mint egy évvel ezelött,

- gyakran vásárolok környezetbarát terméket, bioélelmiszert,

- nem vásárolom meg olyan cégek termékeit, amelyek nem törődnek a környezettel és a társadalmi problémákkal, 
- a mosáshoz nem mosóporokat használok (pl. mosógolyó).

Meg kell jegyezni, hogy mivel jelen tanulmány nem a skálafejlesztésre fókuszál, annak bemutatására terjedelmi okok miatt nem térek ki.
Az előzőekben bemutatott változtatások után a PEBskála harminchét, szigorúan a környezettudatos viselkedésre fókuszáló állítást tartalmaz (1. táblázat). A környezettudatosság meghatározása során a cselekvési szándék helyett a tényleges (valós) cselekvéseket mértem. A válaszadóknak egy dichotóm skálán azt kellett eldön-

A környezettudatos cselekvések skálája (PEB-skála)

1. táblázat

\begin{tabular}{|c|c|c|c|c|c|c|c|}
\hline & Környezettudatos cselekvések & cselekvési típus & $\begin{array}{l}\text { egyéni } \\
\text { haszon }\end{array}$ & $\begin{array}{l}\text { látha- } \\
\text { tóság }\end{array}$ & $\mathbf{N}$ & átlag & szórás \\
\hline 1 & Nem mosok ki addig semmit, amíg össze nem jön egy mosógépnyi adag belöle. & fogyasztáscsökkentés és lemondás & pozitív & nem & 448 & 0,93 & 0,25 \\
\hline 2 & $\begin{array}{l}\text { Amennyiben lecserélek egy háztartási gépet, mindig energiatakarékosabbat vásáro- } \\
\text { lok. }\end{array}$ & környezethatékony termékek fogyasztása & pozitív & nem & 448 & 0,90 & 0,30 \\
\hline 3 & Inkább zuhanyozni szoktam, mint fürödni. & keresletmódosítás & pozitív & nem & 448 & 0,89 & 0,32 \\
\hline 4 & Nem cserélek le semmit csak azért, mert kiment a divatból. & újrahasznosítás, szelektív gyüjtés & kérdőjeles & igen & 448 & 0,81 & 0,39 \\
\hline 5 & A használt elemeket a szeméttel együtt dobom ki a kukába.* & újrahasznosítás, szelektív gyüjtés & negatív & nem & 448 & 0,80 & 0,40 \\
\hline 6 & A papírhulladékot szelektív módon gyüjtöm. & újrahasznosítás, szelektív gyüjtés & negatív & igen & 448 & 0,79 & 0,40 \\
\hline 7 & Étkezés után, illetve mosogatáskor az ételmaradékot a wc-be öntöm.* & újrahasznosítás, szelektív gyűjtés & negatív & nem & 448 & 0,79 & 0,41 \\
\hline 8 & Az üres üvegeket is szelektív módon gyüjtöm. & újrahasznosítás, szelektív gyüjtés & negatív & igen & 448 & 0,78 & 0,41 \\
\hline 9 & Legszivesebben a húst is hússal enném. * & fogyasztáscsökkentés és lemondás & kérdőjeles & igen & 448 & 0,75 & 0,43 \\
\hline 10 & $\begin{array}{l}\text { Előfordult már, hogy valakinek felhívtam a figyelmét arra, hogy nem környezettuda- } \\
\text { tosan viselkedett. }\end{array}$ & tiltakozás, panasz & semleges & igen & 448 & 0,75 & 0,43 \\
\hline 11 & Évente legalább egyszer-kétszer utazom repülőgéppel nyaralni, vagy üzleti ügyben.* & fogyasztáscsökkentés és lemondás & negatív & igen & 448 & 0,71 & 0,45 \\
\hline 12 & A fel nem használt gyógyszereket a szemétbe dobom.* & újrahasznosítás, szelektív gyüjtés & negatív & nem & 448 & 0,70 & 0,46 \\
\hline 13 & Sok újrafelhasznált anyagokból készült terméket (pl. WC-papir) vásárolok. & keresletmódosítás & negatív & igen & 448 & 0,70 & 0,46 \\
\hline 14 & Télen mindig jól befütök, mert nem szeretek pulóverben üldögélni otthon.* & fogyasztáscsökkentés és lemondás & negatív & nem & 448 & 0,70 & 0,46 \\
\hline 15 & A papírszatyrokat jobban kedvelem a mủanyagoktól. & környezethatékony termékek fogyasztása & semleges & igen & 448 & 0,68 & 0,47 \\
\hline 16 & A fürdőszobában légfrissítő-spray-t használok.* & fogyasztáscsökkentés és lemondás & negatív & nem & 448 & 0,66 & 0,47 \\
\hline 17 & Előmosás nélkül mosom ki a koszosabb ruhákat is. & fogyasztáscsökkentés és lemondás & negatív & nem & 448 & 0,64 & 0,48 \\
\hline 18 & Télen is sokáig nyitva tartom az ablakokat, hogy jó friss legyen a levegő a szobában.* & fogyasztáscsökkentés és lemondás & negatív & nem & 448 & 0,61 & 0,49 \\
\hline 19 & $\begin{array}{l}\text { Általában rövid távolságon belül a tömegközlekedést használom, vagy biciklizek } \\
\text { autóhasználat helyett. }\end{array}$ & keresletmódosítás & negatív & igen & 448 & 0,60 & 0,49 \\
\hline 20 & $\begin{array}{l}\text { Általában olyan helyi termékeket, élelmiszert vásárolok, amelyeket nem messziröl } \\
\text { szállítanak ide. }\end{array}$ & keresletmódosítás & negatív & nem & 448 & 0,60 & 0,49 \\
\hline 21 & A sütő tisztítására speciális sütő-tisztító spray-t használok.* & fogyasztáscsökkentés és lemondás & negatív & nem & 448 & 0,58 & 0,49 \\
\hline 22 & Ha egy üzletben műanyagszatyrot adnak, azt mindig elfogadom.* & fogyasztáscsökkentés és lemondás & negatív & igen & 448 & 0,54 & 0,50 \\
\hline 23 & Ha rovarokat fedezek fel a lakásomban, akkor rovarirtó-szerrel irtom ki őket.* & fogyasztáscsökkentés és lemondás & negatív & nem & 448 & 0,54 & 0,50 \\
\hline 24 & $\begin{array}{l}\text { Nem vásárolok olyan termékeket, melyekröl tudomásom van, hogy kifejlesztése során } \\
\text { állatkisérleteket végeztek. }\end{array}$ & tiltakozás, panasz & negatív & nem & 448 & 0,53 & 0,50 \\
\hline 25 & Jóval kevesebb hulladék keletkezik a háztartásunkban, mint egy évvel ezelött. & fogyasztáscsökkentés és lemondás & semleges & igen & 448 & 0,51 & 0,50 \\
\hline 26 & Gyakran vásárolok környezetbarát terméket, bioélelmiszert. & keresletmódosítás & negatív & igen & 448 & 0,48 & 0,50 \\
\hline 27 & Általában városon belül nem használok autót. & keresletmódosítás & negatív & igen & 448 & 0,47 & 0,50 \\
\hline 28 & $\begin{array}{l}\begin{array}{l}\text { Ismerőseimmel, barátaimmal gyakran beszélgetünk különféle környezeti problémák- } \\
\text { ról. }\end{array} \\
\end{array}$ & tagság, támogatás & semleges & igen & 448 & 0,44 & 0,50 \\
\hline 29 & $\begin{array}{l}\text { Nem vásárolom meg olyan cégek termékeit, amelyek nem törödnek a környezettel és } \\
\text { a társadalmi problémákkal. }\end{array}$ & tiltakozás, panasz & negatív & nem & 448 & 0,40 & 0,49 \\
\hline 30 & Szoktam dobozos italokat is inni.* & fogyasztáscsökkentés és lemondás & negatív & igen & 448 & 0,35 & 0,48 \\
\hline 31 & Általában visszaváltható palackos kiszerelésủ italokat vásárolok. & környezethatékony termékek fogyasztása & negatív & igen & 448 & 0,33 & 0,47 \\
\hline 32 & A mosáshoz nem mosóporokat használok (pl. mosógolyó). & keresletmódosítás & negatív & nem & 448 & 0,29 & 0,45 \\
\hline 33 & Autópályán sem vezetek 100 km/óránál gyorsabban. & fogyasztáscsökkentés és lemondás & negatív & igen & 448 & 0,17 & 0,37 \\
\hline 34 & Néha anyagilag is támogatom a környezetvédelmi szervezeteket. & tagság, támogatás & negatív & nem & 448 & 0,17 & 0,37 \\
\hline 35 & Amikor mosok öblítôt is használok.* & fogyasztáscsökkentés és lemondás & negatív & nem & 448 & 0,15 & 0,36 \\
\hline 36 & A wc-kagylót vegyszerek segítségével tisztítom. & fogyasztáscsökkentés és lemondás & negatív & nem & 448 & 0,15 & 0,36 \\
\hline 37 & Tagja vagyok valamilyen környezetvédelmi csoportnak. & tagság, támogatás & semleges & igen & 448 & 0,06 & 0,24 \\
\hline
\end{tabular}


teniük minden egyes cselekvés esetében, hogy az adott állítás inkább jellemző (igen) vagy nem jellemző (nem) rájuk. Mivel a PEB-skálában szerepeltek olyan állítások (Az 1. táblázatban *-gal jelölve), amelyek esetében az igen válasz (jellemző) jelentette a nem környezettudatos cselekvést (pl. szoktam dobozos italokat is inni), ezért ezek a cselekvéseket az elemzés során átkódoltam úgy, hogy minden esetben a nem környezettudatos válaszok a nulla (0) értéket kapták és a környezettudatos válaszok pedig az egy (1) értéket vették fel.

A környezettudatos magatartás felmérése érdekében online kérdőíves megkérdezéses vizsgálatot végeztem 2017. tavaszán. Az önbevallásos, hólabda módszertannal kivitelezett kényelmi mintavétel során összesen 442 fö 18 év feletti megkérdezett szolgáltatott választ. Az alapsokaság, a 18 év feletti magyar lakosság nagysága (8703163 fö) és a mintanagyság (442 fö) alapján megállapítható, hogy 95 százalékos megbízhatósági szinten a minta konfidencia intervalluma 4,66\%. Mind a mintavétel online módja - az internet-hozzáféréssel nem rendelkezők véleménye nem fejeződhetett ki a kutatási eredményekben -, mind pedig annak önbevallásos jellege, azaz mennyire tekinthetők valósnak az önbevalláson alapuló válaszok, a kutatásom korlátait képezik. A súlyozott mintában a nemek aránya (férfiak: 49,4\%, nők: 50,6\%) és a generációk szerinti megoszlása is megegyezik a 18 év feletti magyar lakosságra jellemző arányokkal, azaz az 52-71 éves veteránok 28,9\%ot, a 41-51 év közé eső X-Generáció 18,5\%-ot, a 22-40 éves Y-Generáció 28,9\%-ot, míg a legfiatalabb (18-21 év közötti) Z-Generáció 28,9\%-ot tesz ki. A minta jelentős részét a felsőfokú végzettséggel rendelkezők alkotják (58,2\%), de a középfokú végzettséggel rendelkezők aránya is magas $(38,8 \%)$, míg az alapfokú végzettséggel rendelkezők csupán 3\%-ot tesznek ki. Jelentős arányban fordulnak elő a városlakók (71,3\%), ezzel szemben a községekben élők aránya csupán 20,9\%. A mintában a szellemi tevékenységet végzők, beleértve a tanulókat is $(93,7 \%)$ egyértelmüen felülreprezentáltak a fizikai tevékenységet végzőkkel szemben (6,3\%). A minta sajátosságai alapján kijelenthető, hogy a tanulmány következtetései leginkább a magyar lakosság online hozzáféréssel rendelkező, városlakó, szellemi tevékenységet végző (vagy tanuló) szegmensére vonatkoztathatók.

A környezettudatos cselekvések típusainak elemzése során Meffert és Kirchgeorg (1994) csoportosításából indultam ki, amelyet kiegészítettem a tagság/támogatás cselekvési típussal. Az 1. táblázat cselekvési típus oszlopa jelöli, hogy az egyes környezettudatos cselekvések milyen típusba esnek. A PEB-skála tizenöt fogyasztáscsökkentéssel és lemondással kapcsolatos cselekvést tartalmaz. Hét cselekvés esik a keresletmódosítás és hat darab pedig a környezettudatos panasz, tiltakozás kategóriába. A környezethatékony termékek fogyasztása, a részvétel az újrahasznosításban, szelektív hulladékgyüjtésben és a tagság/ támogatás csoportok egyaránt három-három cselekvést tartalmaznak. Az egyes cselekvési típusok átlagát és szórását az adott típust alkotó cselekvések átlag- és szórásértékeiből számítottam ki.
A környezettudatos cselekvések láthatóságát is az 1 . táblázat foglalja össze. Amennyiben az adott cselekvés végrehajtása mások számára is látható, úgy a táblázat láthatóság oszlopában igen szerepel, amennyiben pedig nem, akkor nem. A PEB-skála tizennyolc látható és tizenkilenc nem látható cselekvést foglal magába.

Ugyanezen táblázat egyéni haszon oszlopa az adott cselekvéshez tartozó egyéni hasznot fejezi ki. Amenynyiben ez pozitív, úgy az egyén a cselekvés végrehajtásával valamilyen mértékű egyéni, közvetlenül érzékelhető haszonra tesz szert, ha pedig negatív, akkor a környezettudatos magatartás valamilyen áldozat meghozatalával jár. Semleges esetben az egyéni haszon és az egyéni ráfordítás mértéke kiegyenlíti egymást, vagy egyik sem jelentkezik. A kérdőjeles csoportba eső cselekvések esetében nem sikerült meghatároznom egyértelmüen a megfelelő kategóriát, ezért ezeket a cselekvéseket kihagytam az egyéni haszonnal foglalkozó elemzésekből. Meg kell jegyeznem, hogy a cselekvések láthatóság és egyéni haszon szerinti kategorizálása teljes mértékben szubjektív volt, amely a kutatásom további korlátját képezi.

\section{EREDMÉNYEK}

\section{A környezettudatos cselekvések gyakorisága}

A környezettudatos cselekvések elöfordulási gyakoriság szerint rendezett rangsorát az 1. táblázat szemlélteti. A táblázat átlag oszlopa a változó dichotóm jellege miatt az egyes cselekvések esetében a környezettudatos módon viselkedők arányát is mutatja. A kutatási eredményeim alapján kijelenthető, hogy a leggyakoribb környezettudatos cselekvés a mosással kapcsolatos. A legtöbben - a válaszadók 93\%-a - nem mosnak ki addig semmit, amíg össze nem jön egy mosógépnyi adag belőle. Ezt követi az energiatakarékos háztartási gép vásárlása („Amennyiben lecserélek egy háztartási gépet, mindig energiatakarékosabbat vásárlok”, 90\%) és a zuhanyzás preferálása („Inkább zuhanyozni szoktam, mint fürödni”, 89\%). Az öt leggyakoribb környezettudatos cselekvésbe a divathatás negligálása („Nem cserélek le semmit csak azért, mert kiment a divatból”, 81\%) és a használt elemek külön gyüjtése („A használt elemeket nem a szeméttel együtt dobom ki a kukába"1, 80\%) került még be.

Ezután következnek azon cselekvések, amelyek esetében a környezettudatosan viselkedők aránya magas, 60-79\% között alakult. Ebbe a csoportba tizenöt cselekvés került. A legtöbben a papírhulladékot szelektív módon gyüjtik (79\%), de sokan vannak azok is, akik az üres üvegekkel is ezt teszik (78\%), illetve étkezés után, illetve mosogatáskor az ételmaradékot nem a wc-be öntik (79\%). A TOP 10-es lista kilencedik helyén a környezettudatos viselkedésre való figyelemfelhívás szerepelt („Előfordult már, hogy valakinek felhívtam a figyelmét arra, hogy nem környezettudatosan viselkedett, 75\%), de sokakra jellemző a mértéktelen húsfogyasztásról való lemondás is (75\%). Azok is sokan vannak (71\%), akik évente egyszer-kétszer sem utaznak repülőgéppel, illetve a fel nem használt gyógyszereket nem a szemétbe dobják (70\%). Azok aránya 
is magas, akikre nem jellemző az az állítás, hogy „Télen mindig jól befütök, mert nem szeretek pulóverben üldögélni otthon, 70\%" és akik sok újrafelhasznált anyagokból készült terméket (pl. WC-papír) vásárolnak (70\%). Hozzávetőlegesen háromból két före (68\%) jellemző, hogy a papírszatyrokat jobban kedvelik a müanyagoktól, illetve a fürdőszobában sem használnak légfrissítő-spray-t (66\%), valamint előmosás nélkül mossák ki a koszosabb ruhákat is (64\%). Hozzávetölegesen tízböl hatan vannak azok, akikre nem jellemzö, hogy télen is sokáig nyitva tartják az ablakokat, hogy jó friss legyen a levegő a szobában (61\%), illetve általában rövid távolságon belül a tömegközlekedést használják, vagy bicikliznek autóhasználat helyett (60\%), illetve vásárlásaik során a helyi termékeket, élelmiszereket preferálják (60\%).

A harmadik csoportba azon cselekvések kerültek, amelyek esetében a környezettudatosan viselkedők aránya közepes mértékü, 40-59\%-ot tett ki. Ebben a csoportban a legjellemzőbb cselekvés a speciális sütő-tisztító spray használatának a kerülése $(58 \%)$, illetve az üzletekben a műanyag szatyrok visszautasítása $(54 \%)$ és a rovarirtószerek használatáról való lemondás (54\%). Hozzávetőlegesen minden második emberre igaz, hogy nem vásárol olyan termékeket, melyekröl tudomása van, hogy annak kifejlesztése során állatkísérleteket végeztek (53\%), illetve akik egyetértenek azzal az állítással, hogy jóval kevesebb hulladék keletkezik a háztartásukban, mint egy évvel ezelőtt (51\%). A válaszadók 48\%-a vásárol gyakran környezetbarát terméket, bioélelmiszert és körülbelül ugyanennyien vannak, akik általában városon belül nem használnak autót (47\%). Ettől kevesebben beszélgetnek gyakran ismerőseikkel, barátaikkal különféle környezeti problémákról (44\%). Csupán tízből négy válaszadóra jellemző, hogy nem vásárolja meg olyan cégek termékeit, amelyek nem törödnek a környezettel és a társadalmi problémákkal (40\%).

A negyedik csoportba azok a magatartásformák tartoznak, ahol a környezettudatos módon viselkedők aránya alacsony, csupán 20 és $39 \%$ között mozog. Ide csupán három cselekvés tartozik. Háromból csupán hozzávetőlegesen egy fö nem szokott dobozos italokat is fogyasztani (35\%), illetve jellemző rá a visszaváltható palackos kiszerelésű italok vásárlása (33\%), de kevesen vannak azok is, akik a mosáshoz nem mosóporokat használnak, hanem valamilyen környezettudatos megoldást vesznek igénybe (29\%).

Az ötödik csoportba azok a cselekvések tartoznak, ahol a környezettudatosan viselkedők aránya nagyon alacsony, a 20\%-ot sem éri el. Csak nagyon kevesen vannak, akik autópályán sem vezetnek 100 km/óránál gyorsabban $(17 \%)$, illetve néha anyagilag is támogatják a környezetvédelmi szervezeteket (17\%), de azok aránya még kisebb, akikre az a jellemző, hogy a wc-kagylót nem vegyszerek segítségével tisztítják (15\%), vagy amikor mosnak, nem használnak öblítőt (15\%). A legkevesebben azonban azok vannak, akik jelenleg is tagjai valamilyen környezetvédelmi csoportnak, szervezetnek (6\%).

Mindezek megerősítik Hofmeister-Tóth, Kasza-Kelemen és Piskóti (2013) eredményeit, akik kimutatták, hogy a magyar lakosság leggyakrabban az energia- és vízmegtakarításhoz kapcsolódó környezettudatos cselekvéseket végzi. Az is közös vonása a két kutatásnak, hogy ezt a cselekvési típust a hulladékcsökkentéshez kapcsolódó magatartásformák követik és a legkevésbé jellemző hazánkra a környezetvédő szervezetek anyagi támogatása, illetve a bennük lévő tagság. A közlekedéshez kapcsolódó cselekvések azonban a saját eredményeim szerint nem annyira környezettudatosak, mint amilyennek azt Hofmeister-Tóth, Kasza-Kelemen és Piskóti (2013) találták. Meg kell jegyezni, hogy ez utóbbi kutatás településtípusra, régióra, nemre és korra is reprezentatív volt, ami magyarázatot adhat az elérö eredményekre.

\section{Az egyéni haszon szerepe}

Az egyéni haszon egyértelmüen pozitiv hatást gyakorol a környezettudatos cselekvés bekövetkezésére, ugyanis az egyén számára közvetlenül is érzékelhető hasznot hozó cselekvések következnek be a leggyakrabban a kutatási eredményeim szerint. A három leggyakoribb környezettudatos cselekvés hátterében közvetlenül is megfigyelhető az egyéni haszon. Ezek közé tartozik víz- és energiatakarékossággal járó, az egyén pénztárcáját kímélő tudatos mosás, az energiatakarékos háztartási gépek vásárlása és a vízdíjat kevésbé terhelö zuhanyzás, a fürdőzés helyett. Mivel a környezettudatos cselekvések általában egyéni haszonáldozattal járnak, ezért a felmérésemben több egyéni hasznot növelő cselekvés ezeken kívül nem is szerepelt (1. táblázat).

\section{A környezettudatos cselekvési típusok}

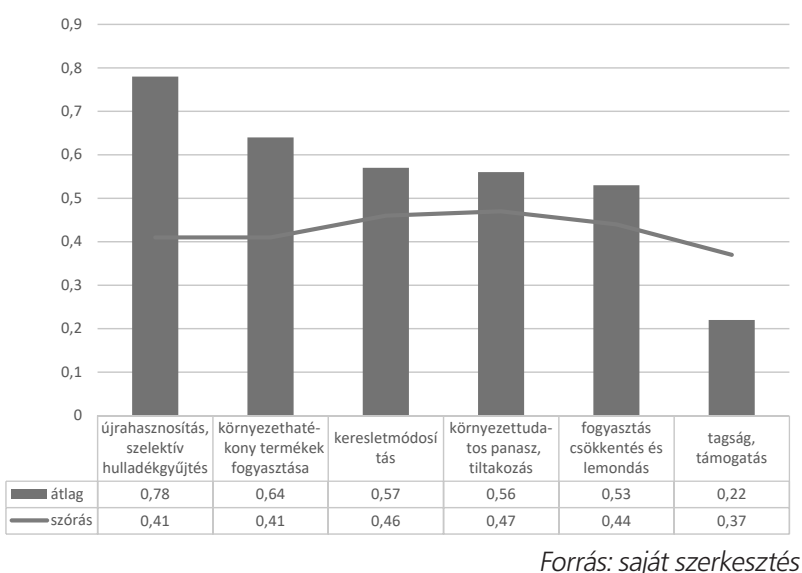

\section{A cselekvési típusok elemzése}

A Meffert és Kirchgeorg (1994) csoportosítása szerinti cselekvési típusok esetében a kutatási eredmények alapján az derült ki, hogy az újrahasznosításban és a szelektív hulladékgyüjtésben való részvétel a leggyakoribb ( 1 . ábra). Az ehhez a típushoz tartozó cselekvések esetében a válaszadók 78\%-a aktív. Ezt követi a környezethatékony termékek fogyasztása, amelyben a felmérésben résztvevők közel kétharmada részt vesz. A környezetbarát termékek felé történő keresletmódosítás esetében mért érték azt fejezi ki, hogy a válaszadók 57\%-a hajlandó ténylegesen a 
környezetbarát termékek vásárlására a hagyományos változatok helyett. A környezettudatos panasz és tiltakozás szintje megközelítőleg ugyanekkora, hiszen a válaszadók $56 \%$-a aktív az ilyen jellegü cselekvések végzésében. A fogyasztás csökkentése és a lemondás a válaszadók 53\%ra jellemző. Eredményeim szerint a legkevésbé jellemző környezettudatos cselekvési típus a tagság/támogatás, amely mindössze a válaszadók csupán $22 \%$-át érinti. A változó dichotóm jellege miatt az átlagértékek az egyes cselekvési típusok esetében a környezettudatos módon viselkedők arányát is mutatják.

\section{A cselekvési nehézségek}

Mivel a PEB-skálát alkotó cselekvések eltérő nehézségüek, a környezettudatos magatartás objektív mérése érdekében kiszámítottam az egyes cselekvésekhez kapcsolódó cselekvési nehézségeket is. Általánosságban, ha két cselekvés közül az egyiket jóval többen hajtják végre környezettudatos módon (pl. energiatakarékos gépek vásárlása), akkor az a cselekvés kisebb cselekvési nehézséggel rendelkezik, mint a másik (pl. környezetvédelemmel foglalkozó szervezetek anyagi támogatása). Tehát, ha valaki egy környezeti szempontból nehezebb cselekvést hajt végre, az nagyobb súllyal szerepel az adott személy környezettudatosságának meghatározása során. Az adott cselekvés nehézségparaméterének meghatározása úgy történik, hogy az adott cselekvés (i) szempontjából környezettudatosan viselkedők számának $\left(\mathrm{n}_{\mathrm{KT}}\right)$ és az összes válaszadó számának $(\mathrm{N})$ hányadosát képezzük az adott cselekvés (i) vonatkozásában, majd pedig az így kapott értéket kivonjuk 1-böl, azaz a nehézség paraméter (NEH) meghatározható az 1. képlet segítségével.

\section{A környezettudatos cselekvések nehézségi paramétere}

$$
\mathrm{NEH}(\mathrm{i})=1-\left(\mathrm{n}_{\mathrm{KT}}(\mathrm{i}) / \mathrm{N}\right)
$$

\section{A környezettudatos cselekvések cselekvési nehézségei}

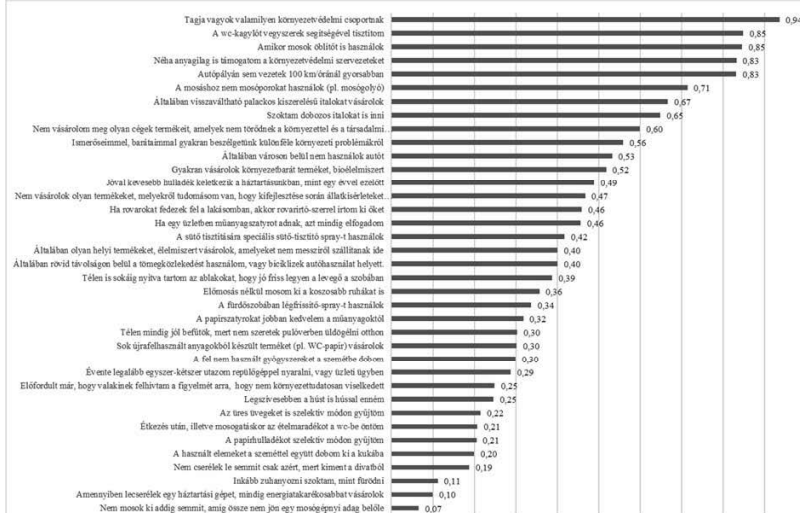

Megjegyzés: (0: extrém könnyű ... 1: extrém nehéz) Forrás: saját szerkesztés

1. képlet

2. ábra
A kutatási eredményeim alapján megállapítható (2. ábra), hogy a legnehezebb környezettudatos cselekvés valamilyen környezetvédelmi csoport tagjának lenni $(0,94)$, de csak kissé könnyebb az öblítőről való lemondás $(0,85)$, vagy a vegyszermentes WC-kagyló tisztítás $(0,88)$, illetve a környezetvédelmi szervezetek anyagi támogatása $(0,83)$, valamint a maximum $100 \mathrm{~km} /$ órás, nem túl gyors tempójú vezetés az autópályán $(0,17)$. Ezzel szemben a legkönnyebb cselekvés a tudatos mosás $(0,07)$, illetve az energiatakarékos háztartási gép vásárlása $(0,10)$, valamint a zuhany használata fürdés helyett $(0,11)$.

\section{A környezettudatos magatartás és annak önértékelése}

Az egyes válaszadók tényleges környezettudatosságának meghatározása érdekében minden válaszadó esetében az általa véghez vitt környezettudatos cselekvések nehézségi paraméterekkel súlyozott összegét képeztem, amelyet azután a nehézségi paraméterek összegével elosztva a 0 és 1 közötti értéktartományra transzformáltam. A számítás eredményeképpen, ha valaki egy cselekvés esetében sem viselkedik környezettudatosan, akkor a PEB-skála nulla (0) értéket, ha minden cselekvés esetében környezettudatos viselkedik, akkor egy (1) értéket vesz fel. A válaszadók tényleges környezettudatos magatartás szerinti százalékos megoszlását a 3. ábra szemlélteti. Az x tengelyen a környezettudatosság mértéke látható, amely 0 és 1 közötti értéktartományban mozoghat, az y tengelyen az x tengelyen leolvasható mértékben környezettudatosan viselkedők százalékos arányát láthatjuk.

3. ábra

A válaszadók tényleges környezettudatosság szerinti

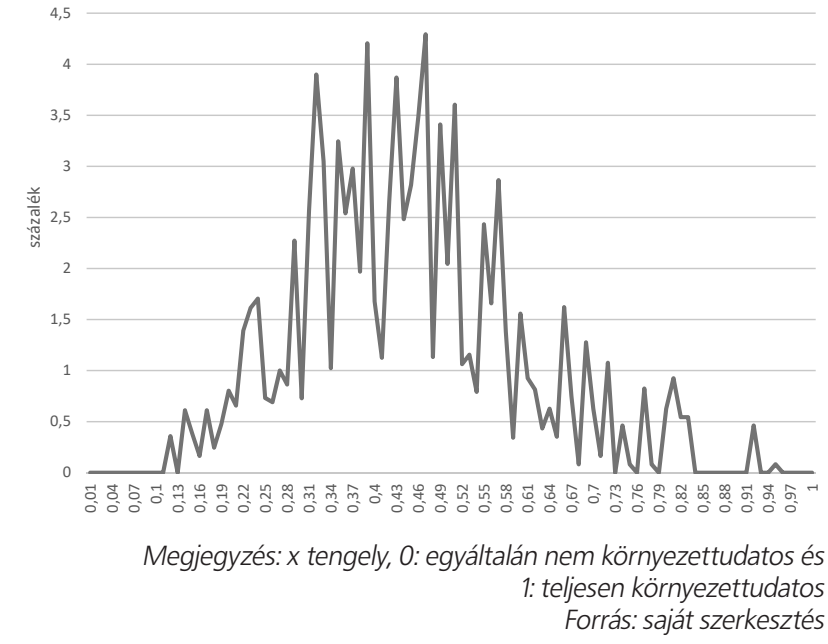

A válaszadók jelentős része egyáltalán nem viselkedik környezettudatosan, azaz cselekvéseinek jelentős része esetén nem számol azok környezeti konzekvenciáival. A környezettudatos magatartás átlagos foka, azaz a PEB átlagértéke mindössze 0,45 , azaz a közepes mértékűnél is alacsonyabb (2. táblázat). A tényleges környezettudatos magatartás görbe a kevésbé környezettudatos területek felé tartalmaz több elemet, azaz baloldali aszimmetriával 
rendelkezik $(\mathrm{F}=0,51)$, illetve mivel a csúcsosság pozitív (Kurtosis=0,24), így a sokaság eloszlásának sürüségfüggvénye csúcsosabb, mint a normális eloszlás haranggörbéje.

2. táblázat

\section{A környezettudatos magatartás (PEB)} alapstatisztikai mutatói

\begin{tabular}{|l|l|c|}
\hline \multirow{2}{*}{ PEB érték (0-1) } & Érvényes & 442 \\
\cline { 2 - 3 } & Hiányzó & 0 \\
\hline Átlag &, 45 \\
\hline Medián &, 43 \\
\hline Modusz &, 47 \\
\hline Szórás &, 15 \\
\hline Ferdeség (Skewness) (F) &, 51 \\
\hline A ferdeség standard hibája &, 12 \\
\hline Csúcsosság (Kurtosis) &, 24 \\
\hline A csúcsosság standard hibája &, 23 \\
\hline \multirow{3}{*}{ Percentilisek } &, 32 \\
\hline \multirow{2}{*}{} & 20 &, 39 \\
\cline { 2 - 3 } & 40 &, 47 \\
\cline { 2 - 3 } & 60 &, 56 \\
\cline { 2 - 3 } & 80 & \multicolumn{2}{|c|}{} \\
\hline \multicolumn{2}{|l|}{ Forrás: saját szerkesztés }
\end{tabular}

Mindezek után a válaszadók tényleges környezettudatos magatartásuk alapján történő szegmentálást végeztem el, melynek során a válaszadókat öt csoportra bontottam (4. $a ́ b r a)$. Az első csoportot alkotják azok az egyáltalán nem környezettudatos fogyasztók, akik esetében a PEB-skálán mért érték nem érte el a 0,2-t. Az ő részarányuk a teljes mintán belül 2,85\%-ot tesz ki. A második, kis mértékben környezettudatos csoportba azok kerültek, akik esetében a PEB-érték 0,21 és 0,40 között alakult (36,10\%), míg a harmadik, közepes mértékben környezettudatos csoportba azok, akik esetében 0,41 és 0,60 közé esett a tényleges környezettudatos magatartás kalkulált mértéke. Ennek a csoportnak a részaránya a legmagasabb a mintán belül (46,03\%). A nagymértékben környezettudatos csoportot (11,84\%) azok alkotják, akik esetében a PEB-érték 0,61 és 0,8 közé esett, míg a teljesen környezettudatos csoportba azok kerültek, akik esetében a legmagasabb, 0,81 és 1,00 közé eső PEB-értékkel rendelkeztek (3,18\%). Ez tulajdonképpen a válaszadók viselkedésalapú szegmentációjának felel meg, hiszen az egyének a tényleges környezettudatos magatartásuk alapján kerültek a számukra megfelelő csoportba.

A környezettudatos magatartás önértékelése során a megkérdezetteknek arra a kérdésre kellett választ adniuk, hogy mennyire tartják magukat környezettudatosnak. A válaszlehetőségek a fenti szegmenskategóriákat tartalmazták, tehát az egyáltalán nem környezettudatostól a teljesen környezettudatosig terjedtek.

A 4. ábra érzékelteti az önértékelés és a tényleges értékelés közötti szakadékot. A válaszadók környezettudatosság szerinti önértékelése a valóságnál jóval kedvezőbb, azaz sokkal pozitívabb színben látjuk magunkat annál, mint ahogyan ténylegesen viselkedünk. Ezt igazolja, hogy a nagymértékben környezettudatos kategóriába csupán a válaszadók 11,84\%-ka került, holott 46,74\% előzetesen ebbe a kategóriába sorolta be magát, míg a teljesen környezettudatos szegmensben is csupán 3,18\% a ténylegesen ide tartozók aránya, szemben az önértékelés során megadott 7,90\%-kal. Ugyanígy a kismértékben környezettudatos szegmensben a ténylegesen ide tartozók aránya $(36,1 \%)$ lényegesen meghaladja azok arányát, akik saját magukat ide sorolták be előzetesen (5,18\%). De ugyanez látható az egyáltalán nem környezettudatos szegmensben is, ahová csupán a válaszadók $0,16 \%$-ka helyezte magát önbevallás alapján, holott a valóságban a megkérdezettek 2,85\%-ka tartozik ide.

\section{A környezettudatos viselkedés értékelése és önértékelése}

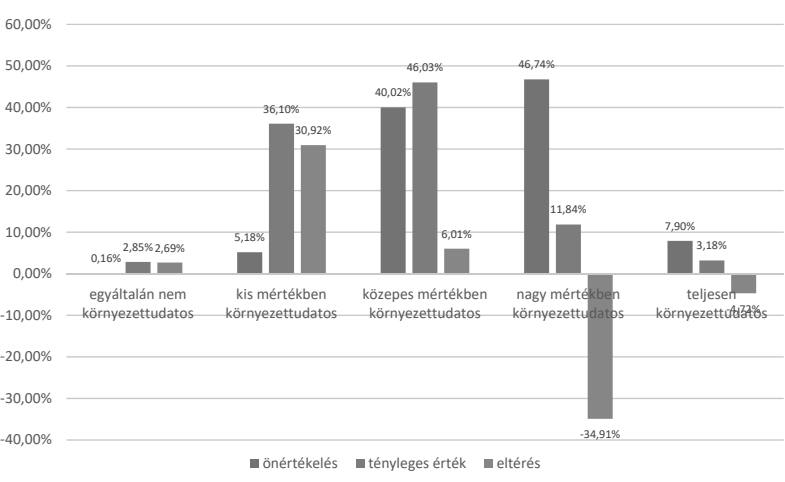

Forrás: saját szerkesztés

A fenti eredmények alapján azt a hipotézist állítottam fel, hogy az önértékelés szignifikáns módon kedvezőbb a környezettudatos viselkedés tényleges mértékénél (H3). A hipotézis tesztelése érdekében Mann-Whitney-Wilcoxon-próbát végeztem, amely egy legalább ordinális változó mediánját hasonlítja össze két, egymástól független csoportnál. A próba nullhipotézise, hogy a mediánok megegyeznek a két csoportban. A próba végrehajtásának nincs elöfeltétele. Az egyik csoportba az önbevallás értékei kerültek, a másik csoportot a környezettudat ténylegesen számított értékei alkotják.

A 3. táblázatból kiolvasható, hogy szignifikáns különbség mutatkozik a két csoport között. A tényleges környezettudat általam mért szintje alacsonyabb az önbevallás során rögzítettnél, ugyanis esetükben a rangszámok átlaga kisebb, mint az első csoportnál.

3. táblázat

\section{A Mann-Whitney-Wilcoxon-próba mutatói}

\begin{tabular}{|c|c|c|c|c|}
\hline & Csoport & $\mathrm{N}$ & $\begin{array}{c}\text { rangok } \\
\text { átlaga }\end{array}$ & $\begin{array}{c}\text { rangok } \\
\text { összege }\end{array}$ \\
\hline \multirow{2}{*}{$\begin{array}{c}\text { A kör- } \\
\text { nyezet- } \\
\text { tudat } \\
\text { mértéke }\end{array}$} & $\begin{array}{c}\text { önértékelés alapján } \\
(1,00)\end{array}$ & 444 & 564,58 & 250673,00 \\
\cline { 2 - 5 } & $\begin{array}{c}\text { ténylegesen mért } \\
\text { PEB alapján (2,00) }\end{array}$ & 444 & 324,42 & 144043,00 \\
\cline { 2 - 5 } & Összesen & 888 & & \\
\hline
\end{tabular}

Forrás: saját szerkesztés 
Hogy ez a különbség szignifikáns-e, az attól a szignifikanciaértéktől függ, ami a próbastatisztika értékéhez $(Z=-$ 14,853) tartozik. Ebben az esetben a különbség erősen szignifikáns (4. táblázat).

4. táblázat

Tesztstatisztika

\begin{tabular}{|l|c|}
\hline & $\begin{array}{c}\text { A környezettudat } \\
\text { mértéke }\end{array}$ \\
\hline Mann-Whitney U & 45253,000 \\
\hline Wilcoxon W & 144043,000 \\
\hline$Z$ & $-14,853$ \\
\hline szignifikancia (2-oldalú) &, 000 \\
\hline $\begin{array}{l}\text { a. csoportképző változó: a környe- } \\
\text { zettudat megállapításának módja } \\
\text { (önértékelés/mérés) }\end{array}$ & \\
\hline
\end{tabular}

Forrás: saját szerkesztés

A H3 hipotézist tehát elfogadom, amiből az következik, hogy a környezettudatosság önértékelése a ténylegesen mértnél szignifikáns mértékben kedvezöbb.

\section{A láthatóság környezettudatos magatartásra gyakorolt hatása}

A láthatósággal kapcsolatos első két hipotézis (H1 és H2) tesztelése érdekében a látható és nem látható cselekvések átlagait hasonlítottam össze elöször az összes válaszadóra, majd a nem vagy egyáltalán nem környezettudatosan viselkedőkből és a nagy vagy teljes mértékben környezettudatos kategóriába esőkből képzett csoportokra vonatkozóan. A vizsgálat során minden egyes válaszadó esetében a látható és nem látható cselekvések átlagait képeztem, majd páros t-próba segítségével hasonlítottam össze az átlagokat. A páros t-teszt segítségével feltártam, hogy az összes válaszadó esetében a látható és nem látható környezettudatos cselekvések átlagai között nem mutatkozik szignifikáns eltérés (5. táblázat), így az első hipotézist (H1) elvetem, azaz a környezettudatos cselekvések láthatósága nem gyakorolt pozitiv hatást azok bekövetkezésére.

A 6. táblázat azt szemlélteti, hogy a látható cselekvések átlaga (átlag=0,5533) szinte alig haladja meg a nem látható cselekvések átlagát (átlag=0,5495).

Ugyanakkor a környezettudat alapján képzett csoportok esetében végzett páros t-próba segítségével sikerült igazolni a H2 hipotézist, ugyanis a nem vagy egyáltalán nem környezettudatos, illetve a nagy vagy teljes mértékben környezettudatos szegmensbe tartozók esetében is szignifikáns eltérés (5\% szignifikanciaszinten) mutatkozott a látható és nem látható cselekvések átlagai között (7. táblázat). A nem vagy egyáltalán nem környezettudatos válaszadók esetében a látható cselekvések átlaga (átlag=0,4029) szignifikánsan alacsonyabb volt a nem látható cselekvések átlagától (átlag=0,4416), míg a nagy vagy teljes mértékben környezettudatos szegmensbe tartozók esetében a látható cselekvések átlaga (átlag=0,7863) szignifikánsan magasabb a nem látható cselekvések átlagától (átlag=0,7466) (8. táblázat).

6. táblázat

A páros t-próba statisztika (összes válaszadó)

\begin{tabular}{|l|l|l|l|l|l|}
\hline \multicolumn{2}{|c|}{} & átlag & $\mathrm{N}$ & szórás & standard hiba \\
\hline \multirow{2}{*}{ Pár 1 } & látható &, 5532 & 448 &, 17580 &, 00831 \\
\cline { 2 - 6 } & nem látható &, 5495 & 448 &, 13666 &, 00646 \\
\hline \multicolumn{6}{|c|}{ Forrás: saját szerkesztés }
\end{tabular}

A páros t-próba eredménye (összes válaszadó)

5. táblázat

\begin{tabular}{|c|c|c|c|c|c|c|c|c|c|}
\hline & \multicolumn{5}{|c|}{ a két változó különbsége } & \multirow{3}{*}{$\mathrm{t}$} & \multirow{3}{*}{ df } & \multirow{3}{*}{$\begin{array}{l}\text { Szig. } \\
\text { (2-oldalú) }\end{array}$} \\
\hline & & \multirow{2}{*}{ átlag } & \multirow{2}{*}{ szórás } & \multirow{2}{*}{ standard hiba } & \multicolumn{2}{|c|}{ 95\% konfidencia intervallum } & & & \\
\hline & & & & & alsó & felső & & & \\
\hline Pár 1 & $\begin{array}{l}\text { látható - } \\
\text { nem lát- } \\
\text { ható }\end{array}$ & ,00364 &, 15854 & ,00749 &,- 01109 & 01837 & ,486 & 447 & ,627 \\
\hline
\end{tabular}

Forrás: saját szerkesztés

7. táblázat

A páros t-próba eredménye (környezettudat szerinti csoportok)

\begin{tabular}{|c|c|c|c|c|c|c|c|c|c|c|}
\hline \multirow{3}{*}{\multicolumn{3}{|c|}{ Környezettudat szerinti csoportok }} & \multicolumn{5}{|c|}{ a két változó különbsége } & \multirow{3}{*}{$\mathrm{t}$} & \multirow{3}{*}{ df } & \multirow{3}{*}{$\begin{array}{c}\text { Szig. } \\
\text { (2-oldalú) }\end{array}$} \\
\hline & & & \multirow[t]{2}{*}{ átlag } & \multirow[t]{2}{*}{ szórás } & \multirow{2}{*}{$\begin{array}{c}\text { standard } \\
\text { hiba }\end{array}$} & \multicolumn{2}{|c|}{$\begin{array}{c}95 \% \text { konfidencia } \\
\text { intervallum }\end{array}$} & & & \\
\hline & & & & & & alsó & felsö & & & \\
\hline $\begin{array}{c}\text { nem vagy egyáltalán nem } \\
\text { környezettudatosak }\end{array}$ & pár 1 & $\begin{array}{l}\text { látható - } \\
\text { nem látható }\end{array}$ &,- 03871 & , 15104 & 01139 &,- 06119 &,- 01622 & $-3,398$ & 175 &, 001 \\
\hline $\begin{array}{l}\text { nagy vagy teljes mérték- } \\
\text { ben környezettudatosak }\end{array}$ & pár 1 & $\begin{array}{l}\text { látható - } \\
\text { nem látható }\end{array}$ & 03970 & ,12421 &, 01524 & ,00926 & ,07014 & 2,604 & 65 & ,011 \\
\hline
\end{tabular}


Ez alapján kijelenthető, hogy az átlagosnál jóval környezettudatosabb egyének esetében a cselekvés láthatósága növeli annak bekövetkezési esélyeit, míg a nem, vagy egyáltalán nem környezettudatos egyének esetében csökkenti azt. A saját kutatási eredményeim tehát összhangban vannak a nemzetközi kutatási eredményekkel (Brick - Sherman - Kim, 2017).

8. táblázat

\section{A páros t-próba statisztika (környezettudat szerinti csoportok)}

\begin{tabular}{|c|c|c|c|c|c|c|}
\hline \multicolumn{3}{|c|}{$\begin{array}{l}\text { Környezettudat szerinti } \\
\text { csoportok }\end{array}$} & átlag & $\mathrm{N}$ & szórás & $\begin{array}{l}\text { standard } \\
\text { hiba }\end{array}$ \\
\hline \multirow{2}{*}{$\begin{array}{l}\text { nem vagy } \\
\text { egyáltalán } \\
\text { nem kör- } \\
\text { nyezettu- } \\
\text { datosak }\end{array}$} & \multirow[b]{2}{*}{$\begin{array}{c}\text { pár } \\
1\end{array}$} & látható & ,4029 & 176 & , 12296 & ,00927 \\
\hline & & $\begin{array}{l}\text { nem } \\
\text { látható }\end{array}$ & ,4416 & 176 & 08990 & ,00678 \\
\hline \multirow{2}{*}{$\begin{array}{l}\text { nagy vagy } \\
\text { teljes } \\
\text { mértékben } \\
\text { környezet- } \\
\text { tudatosak }\end{array}$} & \multirow[b]{2}{*}{ pár } & látható & ,7863 & 66 & 09279 & 01139 \\
\hline & & $\begin{array}{l}\text { nem } \\
\text { látható }\end{array}$ & ,7466 & 66 & ,07905 & ,00970 \\
\hline
\end{tabular}

Forrás: saját szerkesztés

\section{KÖVETKEZTETÉSEK, JAVASLATOK}

A kutatási eredményeim alapján kijelenthető, hogy a környezeti marketing egyik legfontosabb feladata a hamis önértékelés tudatosítása az egyéni felelősség fontosságának hangsúlyozásával. Amennyiben az egyének tudatában lesznek annak, hogy valójában sokkal kevésbé viselkednek környezettudatosan, mint azt gondolják magukról, úgy nőhet a környezettudatos cselekvési szándék valószínüsége, hiszen a környezetterheléssel kapcsolatos ismeretek és a környezettudatos magatartás között szignifikáns pozitív kapcsolat létezik (Nagy, 2005)

Addig azonban, amíg az egyének sokkal pozitívabban ítélik meg a környezettudatos magatartásukat, mint az amilyen valójában, a magatartásuk megváltoztatásán sem fognak gondolkodni. A környezeti attitüdök megváltoztatása során az ismereti komponens erősítésének, azaz a felvilágosításnak a fontosságát támasztja alá, hogy a kutatási eredményeim szerint az újrahasznosításban és a szelektív hulladékgyüjtésben való részvétel a leggyakoribb cselekvési típus, az amely esetében a felvilágosításra eddig a legnagyobb hangsúlyt fektették, amely területen a legtöbb környezetvédelmi kampány történt.

A magatartásformálás legnagyobb akadálya, hogy a környezettudatos cselekvések közül csak igen kevés okozza az egyéni haszon azonnali növekedését, holott ezek a cselekvések a legnépszerübbek a válaszadók körében. Az észlelt egyéni haszonra közvetlenül hatást nem gyakorló cselekvéstípusok egyáltalán nem népszerüek. Ezért, a kutatási eredmények alapján, például ha növelni szeretnénk a környezettudatos vásárlók számát, akkor a termékek hirdetésében azt kell hangsúlyozni, hogy a fogyasztónak milyen előnye származik a környezettudatos termékek vásárlásból.

Azt is fontosnak tartom megjegyezni, hogy a környezettudatos cselekvések láthatósága esetén fontos az egyes környezettudat szintje alapján csoportok megkülönböztetése: a környezettudatosan viselkedő személyeket nem szabad ugyanúgy kezelni, mint a nem környezettudatosokat. Ennek oka, hogy az átlagosnál jóval környezettudatosabb egyének esetében a környezettudatos cselekvés láthatósága növeli annak bekövetkezési esélyeit, míg a nem, vagy egyáltalán nem környezettudatos egyének esetében csökkenti azt.

Összességében a kutatási eredményeim alapján kijelenthető, hogy az emberek „hamis elégedettségének” a megváltoztatása szükséges ahhoz - speciálisan az adott szegmensre szabott felvilágosító kampányok segítségével -, hogy fenntarthatóbb magatartási mintákat követve a környezettudatos magatartás jelenlegi nagyon alacsony szintjéről felfelé tudjunk elmozdulni.

\section{Felhasznált irodalom}

Bateson, M. - Callow, L. - Holmes, J. R. - Roche, M. L. - Nettle, D. (2013): Do Images of 'Watching Eyes' Induce Behaviour That Is More Pro-Social or More Normative? A Field Experiment on Littering. PLoS ONE, 8(12). doi:10.1371/journal.pone.0082055

Boldero, J. (1995) The prediction of household recycling of newspapers: the role of attitudes, intentions, and situational factors. Journal of Applied Social Psychology, 25, p. 440-462.

Brick, C. - Sherman, D.K. - Kim, H.S. (2017): "Green to be seen" and "brown to keep down": Visibility moderates the effect of identity on pro-environmental behavior. Journal of Environmental Psychology, 51, p. 226-238. doi:10.1016/j.jenvp.2017.04.004

Guerrero, L.A. - Maas, G. - Hogland, W. (2013): Solid waste management challenges for cities in developing countries. Waste Management, 33, p. 220-232.

Griskevicius, V. - Tybur, J. M. - Van den Bergh, B. (2010): Going green to be seen: Status, reputation, and conspicuous conservation. Journal of Personality and Social Psychology, 98(3), p. 392-404. https://doi. org/10.1037/a0017346

Hirschman, A. O. (1970) Exit, voice and loyalty: responses to decline in forms, organizations and states. Boston: Harvard University Press

Hofmeister-Tóth, Á. (2003): Fogyasztói magatartás. Budapest: Aula Kiadó Kft.

Hofmeister-Tóth, Á. (2016): Fogyasztói értékek, trendek és magatartás, Vezetéstudomány, XLVII. évf., Marketingtudományi Különszám, p. 26-29.

Hofmeister-Tóth, Á. - Kasza-Kelemen, K. - Piskóti, M. (2013): A környezetbarát fogyasztói magatartás formái, motivációi és a hátterükben álló pszichográfiai tényezők vizsgálata Magyarországon. Marketing és Menedzsment, 47:(3), p. 34-42.

Kaiser, F. G. (1999): A general measure of ecological behavior. Journal of Applied Social Psychology, 28, p. 395-422. 
Kaiser,F. G.-Wölfing, S.-Fuhrer, U.(1999): Environmental Attitude and Ecological Behaviour. Journal of Environmental Psychology, 19(1), p. 1-19. doi:10.1006/ jevp.1998.0107

Kaiser, F. G. - Wilson, M. (2004): Goal-directed conservation behavior: the specific composition of a general performance. Personality and Individual Differences, 36(7), p. 1531-1544. doi:10.1016/j. paid.2003.06.003

Kaiser, F. G. (1999): A general measure of ecological behavior. Journal of Applied Social Psychology, 28, p. 395-422.

Marshall, R.E. - Farahbakhsh, K. (2013): Systems approaches to integrated solid waste management in developing countries. Waste Management, 33, p. 988-1003.

Meffert, H. - Kirchgeorg, M. (1994): Grundlagen des Umweltschutzes aus wettbewerbsstrategischer Perspektive. Marktorientiertes Umweltmanagement, p. 21-57. doi:10.1007/978-3-322-85905-1_3

Nagy, Sz. (2005): Values and Environmentally Conscious Behaviour (ECB), Business Studies, 3:(1), p. 85-99.

Nagy, Sz. - Piskóti, I. - Molnár, L. - Marien, A. (2012): The Relationship Between Values And General Environmental Behaviour. Economics and Management, 17:(1), p. 272-278.

Nordlung, A. M. - Garvil, Y. (2002): Value structures behind proenvironmental behavior. Environmental Behaviour, 34, p. 740-756.

Ojala, M. (2008): Recycling and ambivalence: quantitative and qualitative analyses of household recycling among young adults. Environmental Behaviour, 40, p. 777-797.

Oskamp, S., (2000): Psychological contributions to achieving an ecologically sustainable future for humanity. Journal of Social Issues, 56 (3), p. 373-390.

Pataki, F. (1982): Az én és a társadalmi azonosságtudat. Budapest: Kossuth Kiadó

Piskóti, I. - Nagy, Sz. (2004): ISPA 2000/HU/16/P/PE/004-S számú Miskolci Regionális Hulladékgazdálkodási Projekt Kommunikációs és PR stratégiája. Tanulmány. Miskolc: Miskolci Egyetem

Piskóti, M. (2015): A környezeti identitás szerepe a környezettudatos magatartásban - a mérési lehetőségek értékelése. Vezetéstudomány, XLVI. évf. 2015. 5. szám, p. 13-23.

Rekettye, G. - ifj. Rekettye, G. (2009): A világ jövője - a jövő marketingje. Vezetéstudomány, XXXX. évf, 2. szám, p. 2-8.

Steg, L. - Vlek, C. (2009): Encouraging pro-environmental behaviour: An integrative review and research agenda. Journal of Environmental Psychology, 29, p. 309-317.

Swami, V. - Chamorro-Premuzic, T. - Snelgar, R. - Furnham, A. (2011): Personality, individual differences, and demographic antecedents of self-reported household waste management behaviours. Journal of Environmental Psychology, 31, p. 21-26.

Törőcsik, M. (2017): Fogyasztói magatartás - Insight, trendek, vásárlók. Budapest: Akadémiai Kiadó 